\title{
The Positive Effects of Preschool Education in the Socialization and Learning of Children
}

\author{
Valbona Keçia
}

\begin{abstract}
The purpose of this study is to highlight the positive effects that the attendance of preschool education has on the socialization and on the learning level of children. They are related with the kind of preschool education that the child attends, with the area where the child lives, with the education level of the parents, with the way how the learning process is realized in the kindergarten. Five hundred (500) first graders of the city of Durres are chosen. Parents and teachers will be part of the study only after taking the consent from RIE (Regional Institute of Education). The completed surveys from the parents will create us an idea of the situation how they experience this and what their expectations regarding their children are. Surveillance will be another important method that will be used to give the conclusion of this study. Children will be watched during spontaneous and one-hour made situations. Statistical data from the two groups of children and parents tests will help us prove how visible the positive effects of attending the preschool education on the performance children show during first grade are. At the end of the study, it will be asked to prove that the attendance of preschool education in specialized institutions has positive effects on the development children show in the first grade in the two targets which we have chosen to study.
\end{abstract}

\section{Keywords}

Preschool education, socialization, learning, kindergarten, game, rural-urban

Preschool education is the first level of education in which children are educated at home or at preschool education institutions ${ }^{1}$, from 3-6 years old in preparing classes and 5-6 years old in opened classes near schools. Because of some factors being even social-economical or from our past, in Albania despite some laws or reforms, it is still missing a serious care about the first level of education of children. About the number of children attending preschool education, this has been increasing because of the indication of MES (Ministry of Education and Sport), which has made it obligatory since September 2014 that the child attends at least one year of preschool education, but this has led more in sending the children in this open groups near schools where children are more care about being taught how to write and how to read rather than giving them a through education according to the specialities of the age and value to confront life. A nonpositive background is shown in rural areas where children pass this phase of education with their family. In 2006, it approved the strategy to involve the preschool system in our preuniversity system like its first step to involve children 5-6 years old in the second preparing year. While seeing the statistics of MES, the rhythms of the development of preschool education were low during these 15 last years. Today in the recent statistics of MES for 2014 preschool

aEuropean University of Tirana, Tirana, Albania

Correspondent Author:

Valbona Keçi, Bashkimi Road, nr. 1990, Durres, Albania 
education, public and private is organized in kindergartens and preparing classes where children from 3-6 years old are educated and it is not obligatory. Kindergartens function in three groups and preparing classes function near schools, and they are attended by 5-6 years old children who come straightly from their homes. The learning educative process is in Albanian language according to a curricula which follows the accepted standards of the content and achieving (Mato 1997). According to the statistics [Ministry of Education and Sport (MES) 2014] about $70 \%$ of the children who attend these forms of education, because of the absence of kindergarten, there is a nonpositive approach against the kindergarten. Parents think that it is important for them to be prepared for school. There have been different experiments to reform the curricula but they were unsuccessful. Now in association with the reform, that will include the preuniversity education, in association with the development that our society seeks and in association with the european integration, there will be made a change in the curricula focusing on the development of crucial competences. It has set up a group which supports the best European performance and is associated with the unification of the curriculas with Kosova to build a new curricula for preschool education. Starting from the fact that in USA, in the purposes of the Panel of Education, the care about children in early childhood and achieving an education as good as possible is one of the main purposes of this panel, and from the fact that many done studies around the world (Lipsey et al. 2012) and in Albanian areas too (Gjetja 2014), it has shown that the good interference in early childhood has a high success rule in primary school and further in the whole education of the person. The author thinks that it is the right moment for the preschool education, like a very important phase of the preuniversity education, to be seen with much more importance, and thinks that his study which has focusd on the evidence of positive effects of this education in the directions of socialization and learning, can serve at least to make aware of the respective organs and institutions for a higher attention to early childhood and education in this period, like a very important start for the making of a successful individual both from social and academic way. It is very important for the explosion of these children during early childhood against various experiences of life, where they are through playing to be stimulated to develop the affection of the kindergarten in the development of writing and reading; Dervodeli (2011) studied the success of children related with the age when the registration at school is done; and Zuna-Deva (2003) in her book talks about modality, forms, and the importance of the education of the child in the family. In the author's study, he will stop in two fields with a high importance for the child.

\section{PRESANTATION OF THE PROBLEM}

In the author's country, preschool education is not obligatory. For the first time in the registrations made in September 2014 to enter first grade at school, was required, together with other documents, a verification that the child has attended preschool education, but this does not mean that the children who have not attended this education and come from their homes were not accepted at school. In the moment when this study started in Durres, there were chosen children who followed first grade and came both from home and from kindergarten, but the majority were children who had attended preparing classes, and in rural areas around the city, the percentage of children who came from home was higher. From the author's experience in primary education of 16 years and of nine (9) years in preschool, when he had the first grade, in the discussions they made, they said that kindergarten children were better both in results. Today, big cities (Durres, Tirana, Vlora, Shkodra, Korça) have new specifics where parents sometimes because of not knowing or because of the absence of kindergartens 
where the number of children has turned in the major problem or even the unemployment of women, they cannot send children at the full-time kindergarten and send them in kindergartens with part-time (09:00-12:00) where children play and are prepared for school. This makes that when they enter school, they feel under pressure and scared in the new social group which associates them with an emphasized dislevel of academic knowledges according to children who come from a regular attendance of the education process. There are many studies, such as Kamerman (2008) and Gjetja (2014), which make all the parents aware of that it is not important only to invest for the child when he is in high school, but the investation of the child actively in the preschool education helps him to form a better personality and to achieve an academic achievement. It is seen a difference (working for the author's $\mathrm{PhD}$ thesis ${ }^{2}$ ) between the children who have attended a preparing year and those who have attended three years of preschool education. We are studying and evidencing the social skills that these children win and are not shown until the beginning of the first grade differently from the others who come from home. We also have their academic achievements in the first grade with an aim to emphasize the postivie effects pre-school education has. It will be specified the factors that affect the social and academic performance of the child too, like the involvement in the different times, the game, area-rural or urban, educational level of parents, and gender. Thanks to this study, the author seeks to affect in the greater involvement of the child in preschool education with a bigger attention purpose to involve as many children as possible.

\section{THE PURPOSE OF THE STUDY AND HYPOTHESIS}

The purpose of this study is to specify the positive effects of preschool education in winning social skills and academic ready of the children seen during first grade and further. It will be studied that the intervention of independent variables like child gender, area where he lives, educational level of parents, timing of following this phase environment, playing like the deepest activity of the age is used like a tool to achieve better results in learning. Social skills have to do with the field of social-emotional development and the academic ones with the linguistic and mathematics development field of the child. In the author's objectives, he will study these two fields of the development of the child.

\section{First Study Objective}

To analyze the field of the cognitive, social-emotional, mathematical, and linguistic development of children according to independent variables.

(1) Gaming of preschool;

(2) Enviroment of the kindergarten;

(3) Timing of the attendance of preschool education 1-3 years;

(4) Educational level of parents;

(5) Area rural-urban.

\section{Second Study Objective}

To evidence the connection that exists between social and academic skills that children show and the gaming of preschoolers, environment of the kindergarten, gender, area, the educational level of parents, and the timing.

\section{Main Search Question}

How does preschool education affect in the socialization and learning of children?

\section{Main Hypothesis}

Preschool education affects positively in the socialization and learning of children.

\section{Search Question 1}

Does game affect like a way to understand emotions in the socialization and learning of the child? 


\section{Hypothesis 1}

Game affects the socialization and the skill to learn of the child.

\section{Search Question 2}

How does the enviroment affect the socialization and learning?

\section{Hypothesis 2}

The enviroment affects the socialization and learning.

\section{Search Question 3}

Are there any gender differences among children who attend first grade about socialization and learning?

\section{Hypothesis 3}

There exist gender differences among children about socialization and the level of learning that show during first grade and further.

\section{Search Question 4}

Is there a connection between the educational level of parents and social skills and good academic achievements that children show during first grade?

\section{Hypothesis 4}

There exists a connection between the good social skills and academic achievements that children show during first grade and the educational level of parents.

\section{Search Question 5}

Do there exist differences in socialization among children who have attended a year in preschool education (preparing groups) and those who followed all cycles?

\section{Hypothesis 5}

There exists a connection between the years of frequentation of preschool education and social skills and academic achievements that children show.

\section{THE METHODOLOGY OF THE STUDY}

To prove this, the studying hypothesis is extended during a whole year of the first grade. Five hundred (500) first graders of the city of Durres and smaller units of it are chosen to be studied. There are both boys and girls. Parents and teachers will be part of the study only after taking the consent from RIE (Regional Institute of Education). The study will also include school psychologists who will help for a more professional assumption using standard tests for the checking of the children according to the social competences that they show during first grade. The usage of the interviews with teachers and parents will be used to gather their opinions about the problems that are encountered with the children who have attended the kindergarten differently from those who have never frequented one.

(1) The study population;

(2) Asking parents;

(3) Asking children;

(4) Asking teachers;

(5) Surveilances;

(6) Interviews (structured and opened);

(7) Analisis of asking;

(8) Graphics;

(9) Overview.

\section{CONCLUSIONS}

After a thorough analysis of the givens and facts that will be gathered by the work in the area and from the remake of the givens taken from theories, we supported to verify hypothesis, we will prove that preschool education, that children of this age attend in preschool institutions affects positively in the socialization and level of learning that children show during first grade. 


\section{Notes}

1. Personal experience as the director of "SotirNoka" Kindergarten in the city of Durres, Albania.

2. The author is still in the process of finishing his $\mathrm{PhD}$ thesis and now he is collecting all of the materials to revise them and write the final results with his leading professor.

\section{References}

Baldwin, C. N. 2011. School Readiness: Parent Perceptions, Behaviors, and Child Ability Related to Ethnicity and Socioeconomic Status. Retrieved (http://digitalcommons. wku.edu/theses/1049.pdf).

Boyd, J., W. S. Barnett, E. Bodrova, D. J. Leong, D. Gomby, K. B. Robin, and J. T. Hustedt. 2005. Promoting Children's Social and Emotional Development Through Preschool. Retrieved (http://www.groundworkohio.org/resources/ otherresources_pdf/).

Chaplin, T. M., P. M. Cole, and C. Zahn-Waxler. 2005. "Parental Socialization of Emotion Expression: Gender Differences and Relations to Child Adjustment." Emotion 5(1):80-88.

Child Care \& Early Education Glossary. N.d. Retrieved (http://www.researchconnections.org/childcare/childcare-gl ossary).

Coladarci, T. and C. D. Cobb. 2014. Fundamentals of Statistical Reasoning in Education. 4th ed. Oxford: Oxford University Press.

Colman, A. M. 2001. Dictionary of Psychology. Oxford: Oxford University Press.

Conway, D. M. 2010. The Relationship Between Preschool Programming and School Readiness for Rural Children Entering Kindergarten. Mineapolis: Walden University.

Davis-Kean, P. E. 2005. "The Influence of Parent Education and Family Income on Child Achievement: The Indirect Role of Parental Expectations and the Home Environment." Journal of Family Psychology 19(2):294-304.

Dervodeli, J. 2011. Dallimet në Suksesin e Nxënësve të Shkollës Fillore të Regjistruar Para Kohe, me Kohë dhe Paskohe (Changes in the Sucsess of Children in Elementary School Before, in Time and After). Prishtinë: Albas Publishing.

Espinosa, L. M., K. R. Thornburg, and M. C. Mathews. 1997. "Rural Kindergarten Teachers' Perceptions of School Readiness: A Comparison With the Carnegie Study." Early Childhood Education Journal 25(2):119-125.

Gjetja, M. 2014. Efektet e Edukimit Parashkollor ne Gatishmerine per ne Shkolle (Effects of Pre-school Education in Being Ready for School). ( $\mathrm{PhD}$ dissertation). Prishtine: Albas Publishing.
Janus, M. and E. Duku, 2007. "The School Entry Gap: Socioeconomic, Family, and Health Factors Associated With Children's School Readiness to Learn." Early Education and Development 18(3):375-403.

Kamani, P. 2004. "Overview in the Development Theories." Pre-school Education. Institute of Pedagogical Studies, Tiranë.

Kamerman, S. B. 2008. School Readiness and International Developments in Early Childhood Education and Care. Encyclopedia on Early Childhood Development, Columbia University, USA. Retrieved (http://www.childencyclopedia.com/sites/default/files/textes-experts/en/814/s chool-readiness-and-international-developments-in-early-ch ildhood-education-and-care.pdf).

Karaj, T. 2005. Psychology of the Development of Children. 2nd ed. Tiranë: Progress Publishing.

Koliqi, H. 1998. History of International Pedagogy. Vol. 2. Prishtinë: Mesenjtorja e Re Publishing.

Komenski, J. A. 1964. Shkolla Amnore (Mother's School). Beograd: OMBRA GVG Publishing.

Kraja, M. 2012. Pedagogy. Tirane: Mirgeeralb Publishing House.

Lipsey, M. W., K. G. Hofer, C. Bilbery, and D. C. Farran. 2012. Effects of the Tennessee Voluntary Pre-kindergarten Program on School Readiness. Paper from SREE Conference. Retrieved (http://files.eric.ed.gov/fulltext/ ED530634.pdf).

Mato, E. 1997a. "Pre-school Curriculal." An Edition of the Institute of the Curricula and Standards, Pedagogical Magazine, Tirane.

_. 1997b. Femijet nen 6 vjeç (Children Under 6 Years Old). Tirane: MediaPrint Publisher.

Matthews, E. 2008. "Investigating the Association of Parental Influence and Children's School Readiness and Early Academic Achievement: An Analysis Using Early Childhood Longitudinal Study-Kindergarten (ecls-k)." Unpublished $\mathrm{PhD}$ dissertation, The Temple University, Philadelphia, Pennsylvania.

McCallan, S. A. 2010. Influences of School, Classroom and Teacher Characteristics on Children's School Readiness. Department of Human Development. Retrieved (https://www.researchgate.net/publication/277071354_Influ ences_of_School_Classroom_and_Teacher_Characteristics _on_Children's_School_Readiness).

McCormick, C. B. and M. Pressley. 1997. Educational Psychology: Learning, Instruction, Assessment. New York: Longman.

Ministry of Education and Sport (MES). 2014. Strategiia $e$ Arsimitparauniversitar (Strategies of the Pre-university Education). Retrieved (www.arsimi.gov.al/).

Mooney, C. 2000. Theories of Childhood: An Introduction to 
Dewey, Montessori, Ericson, Piaget and Vygotsky. USA: Redleaf Press.

Morris, G. C. and A. A. Maisto. 2008. Psikologjia-Shkenca e Proceseve Mendore dhe e Sjelljes Njerezore (Psychology-Science of Mental Processes and Human Behaviours). 8th ed. Tirane: CDE.

Morrison, G. 2011. Fundamentals of Early Childhood Education. 6th ed. USA: University of North Texas.

Musai, B. 1999. Psikologji e Edukimit (Psychology of Education). Tiranë: OMBRA GVG Publishing.

National Education Goals Panel. 1997. The National Education Goals Report: Building a Nation of Learners. Washington D.C.: US Government Office. Retrieved (http://govinfo. library.unt.edu/negp/reports/97REPORT.PDF).

Osmani, S. 1983. Fjalor i Pedagogjisë (Pedagogy Dictionary). Tiranë: Shtypshkronja eRe Publishing.

Puma, M., S. Bell, R. Cook, C. Heid, P. Broene, F. Jenkins, A. Mashburn, and J. Downer 2012. Third Grade Follow-up to the Head Start Impact Study. Final Report. Washington, D.C.: Office of Planning, Research and Evaluation. Retrieved (http://www.acf.hhs.gov/sites/default/files/opre/ head_start_report.pdf).

Rrapo, S. and N. Babamusta. 2001. "Child, Parent and Math." Booklet for Parents. Tiranë.

Ryan, Y. 2002. "Emerging Indicators of Success and Failure in Borderless Higher Education." A report for the Observatory on Borderless Higher Education, London.

School Sparks. 2013. Understand How Early Childhood Development in 8 Specific Areas Is Critical to School Success. Retrieved (http://www.schoolsparks.com/earlychildhood-development/grossmotor).

Shala, M. 2011. "Në Parashkollor apo në Parafillor" (In Pre-school or in Pre-beggining). Kosova Sot. p. 12. Retrieved (http://www.kosova-sot.info/opinione/ne-parash kollor-apo-ne-parafillor).
2013. "The Impact of Preschool Social-Emotional Development on Academic Success of Elementary School Students." Psychology 4(11):787-791.

Tahiri, K., L. Hajdaraga, and V. Hoti. 1989. Psikologjia Moshore (Psychology According the Age). Tiranë: MediaPrint Publishing.

Tamo, A. and T. Karaj. 2007. Practices of Child Rearing in the Remote North and Suburban Regions in Albania. Study report prepared by Human Development Center, Tirana, Albania. Retrieved (http://www.unicef.org/albania/ Childrearingstudy-Eng.pdf).

Temple, J. A. 2009. "Rural Gaps in Participation in Early Childhood Education." Journal of Agricultural and Applied Economics 41(2):403-410.

Thomai, J., M. Samara, and P. Haxhillazi. 2006. Albanian Language Dictionary. Tirana, Albania: Science Academy of Albania, Institute of Language and Literature.

United Nations Children's Fund. 2011. Joined Hands Better Childhood. The Edward Zigler Center of Child Development and Social Policy, Yale University. Retrieved (http://www.unicef.org/kosovoprogramme/Joined_Hands_E NG_web.pdf).

Unutkan, O. P. 2006. “A Study of Pre-school Children's School Readiness Related to Scientific Thinking Skills." Turkish Online Journal of Distance Education 7(4):78-85.

Zuna-Deva, A. 2003. Edukimi i Parashkollorit në Familje (Education of the Pre-schooler in the Family). Prishtinë: Albas Publishing.

\section{Bio}

Valbona Keçi, Ph.D. candidate, European University of Tirana, Tirana, Albania; research fields: educational policies, reforms and actors. 